\title{
Geografia: algumas palavras sobre minhas motivações e desafios
}

\author{
Sandra Lencioni \\ FFLCH-USP
}

p. $417-440$

\section{revista}

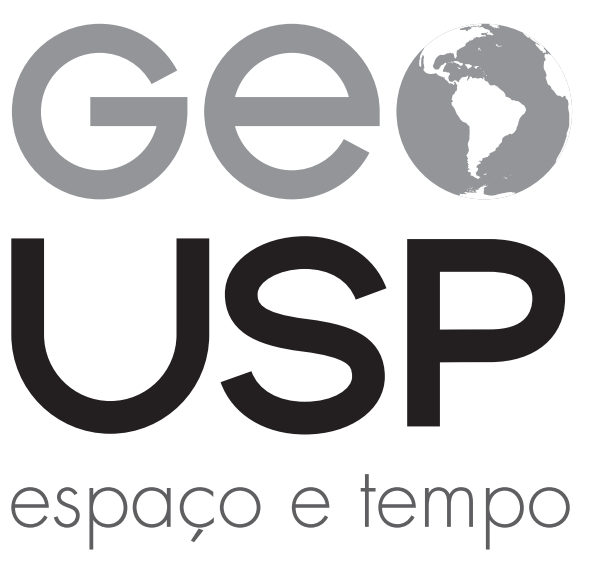

Volume $20 \cdot n^{\circ} 3(2016)$
Como citar este artigo:

LENCIONI, S. Geografia: algumas palavras sobre minhas motivações e desafios. Geousp - Espaço e Tempo (Online), v. 20, n. 3, p. 417-440, mês. 2016. ISSN 2179-0892.

Disponível em: <http://www.revistas.usp.br/geousp/issue/ view/6465>. doi: http://dx.doi.org/10.11606/issn.2179-0892. geousp.2014.84539.

\section{(c) $(1)(9)$}

Este artigo está licenciado sob a Creative Commons Attribution 4.0 License. 


\title{
Geografia: algumas palavras sobre minhas motivações e desafios
}

\section{Resumo}

A carreira universitária tem motivações, implica escolhas e desafios e se desenvolve no ritmo da vida e das conjunturas acadêmicas. Os motivos e porquês nem sempre são claros, pois muitos deles são originados no torvelinho de sentimentos que fogem à razão pura, movidos por vontades e intuições. $\bigcirc$ percurso aqui descrito compreende desde os anos da infância até os da maturidade plena, buscando revelar uma vida dedicada à geografia.

Palavras-chave: Trajetória intelectual. Geografia. Universidade.

\section{Geography: some words about my motivations and challenges}

\begin{abstract}
University life has motivations, implies choices, in facing challenges and develops the rhythm of life and academic situations. The reasons and meanings are not always clear, because many of them are originated in the whirlwind of feelings that are beyond the pure reason, driven by desires and intuitions. The path described here extends from the years of childhood to full maturity for reveal a life devoted to geography.
\end{abstract}

Keywords: Intellectual trajectory. Geography. University.

\section{Introdução}

Olharmo-nos criticamente é imprescindível para compreender nossas motivações e escolhas e revelar o sentido da trajetória percorrida. Enfrentar dificuldades e superar obstáculos expressam êxitos, mas deixam marcas... e os obstáculos que persistem exigem perseverança e esforço e mesmo sabedoria para seguir convivendo com eles. Essa exigência de introspecção deparou com uma espécie de casulo, e era como se ele tivesse uma fechadura que, com a chave da memória, franqueava um profundo mergulho interior pessoal e institucional.

Falar de um percurso acadêmico é dizer das motivações que orientaram o sentido das experiências vividas e dos contextos que o demarcaram, pois uma trajetória acadêmica não pode ser circunscrita em si mesma, mas é parte de estruturas e processos mais gerais, nos quais 
a universidade condensa as determinações da história e ordena o cotidiano. Exige um olhar seletivo e um pinçamento de fatos que me surpreenderam: às vezes, o que me parecia claro ficava opaco e, em outras, o que era obscuro, pela simples necessidade de ser revisto, se esclarecia.

Essa trajetória refere-se, em grande parte, a um século que expirou e que deixou em desamparo os projetos de justiça social. Refere-se a uma universidade cuja fundação, em 1934, se constitui num marco histórico que teve como célula mater a Faculdade de Filosofia, Letras e Ciências Humanas, que é a unidade na qual me formei como geógrafa e é em seu Departamento de Geografia que atuo até hoje.

Uma universidade que fica em São Paulo, uma cidade que tem origem no Colégio de São Paulo dos Campos de Piratininga, fundado por jesuítas. $\bigcirc$ marco zero dessa cidade foi a educação, diferentemente das cidades mais antigas, marcadas por fortificações e localizadas no litoral. Nascida de um simples colégio à margem de um ribeirão secundário, a cidade foi impulsionada pela universidade criada 380 anos depois, nos escombros da derrota da Revolução de 1932. Cidade e universidade se entrecruzam, e é nessa encruzilhada que se situa a produção do conhecimento sobre a cidade, a metrópole e a região, que se tornaram objetos privilegiados de meus estudos.

\section{Minha trajetória intelectual}

A época das liberdades democráticas foi o período de minha formação até a idade adulta. Nasci num tempo marcado pelos escombros da era Vargas, num contexto de comemoração pelo fim da Segunda Guerra Mundial. A Segunda República, que se estendeu de 1945 a 1964, foi um período de liberdade e de democracia, valores constitutivos de minha formação.

Não nasci em São Paulo e nem perto da Cidade Universitária. Da terra onde nasci, Ribeirão Preto, saí aos oito anos para nunca mais retornar, e mesmo esses não foram integralmente vividos ali; vivi algum tempo em São José do Rio Pardo. Morei em várias cidades, em várias casas, e estudei em muitas escolas. Não tenho amigos de infância ou turma de colégio. A graduação da USP, com a falta de turmas seriadas, também não me permitiu viver essa experiência de pertencer a uma determinada turma e comemorar anos de formatura e confraternizar com meus colegas o reencontro dos laços desfeitos.

Mas, se me perguntarem sobre o sentimento de pertencer a um lugar, sobre minha cidade, não tenho dúvida para responder que é a Cidade Universitária meu lugar, porque aí construí raízes. Minha experiência, quase nômade, de crescer sem raízes em razão das contingências da vida familiar, dado que meu pai era um funcionário do Banco do Brasil dedicado à carreira, se constituiu numa rotina até minha juventude.

Minhas primeiras lembranças não são da minha terra natal, mas de São José do Rio Pardo. A casinha de Euclides da Cunha junto à ponte do rio Pardo, onde aos domingos íamos fazer piqueniques, me fez conhecer esse personagem da nossa história, o primeiro de quem ouvi falar. Talvez por esse conhecimento ter acontecido de forma tão terna e simples, referida por uma de suas obras, uma ponte, e por uma modesta casinha no rio em que eu brincava, a história sempre me pareceu próxima e feita por homens comuns; algo de que eu poderia participar.

Quando morei em Santos, já menina, tive a oportunidade de conferir uma das provas acerca da esfericidade da Terra, presentes nas lições escolares da época, que desafiavam a imaginação dos alunos. Eu podia ver o desaparecimento das embarcações navegando na linha do horizonte. Pode parecer banal, mas não era, pois não havia uma imagem da Terra, as que haviam eram montagens de fotos orbitais em 
preto e branco e granuladas e que não tinham divulgação. Só em 1957, quando eu tinha 12 anos, subiu ao céu o primeiro satélite artificial, o Sputnik, lançado pela então União Soviética, e só quatro anos depois, por Yuri Gagárin, o primeiro homem a viajar pelo espaço, ficamos sabendo que, de longe, a Terra é azul.

Em Blumenau, conheci outra cultura e paisagens diversas da paulista e pela primeira vez procurei respostas para a diversidade dos lugares. Mais tarde, essa percepção foi redimensionada muitas vezes, sobretudo quando entrei em contato com a obra de Hartshorne, que entende a geografia como o estudo da diversidade dos lugares. Esse autor acabou me induzindo à Geografia Regional, afastando-me da visão lablachiana e debilitando a ideia de que a geografia se constitui numa ciência voltada para o estudo da relação entre o homem e o meio. Esse caminho foi trilhado com muitas dificuldades, como tantos outros que saem do território protegido das correntes hegemônicas.

Não sei até que ponto minha vida quase nômade e a leitura de relatos de viajantes influenciaram meu interesse pela geografia, até porque gostaria que essa influência tivesse sido maior e mais nítida. Penso que meu respeito e interesse pela pesquisa científica encontra raízes nas obras de ficção de Jules Verne, detentor de um saber geográfico impressionante e leitor de Humboldt, Ritter e Vidal de la Blache.

$\bigcirc$ fato de ter mudado muito de cidade e de escola me trouxe uma experiência muito enriquecedora, pois a convivência com diferentes grupos exigia um comportamento próprio dos camaleões: ou me adaptava, ou corria o risco de ver fenecer minha sociabilidade. Mas também exigia força para viver as experiências de transferência de lugares e escolas, que vêm acompanhadas de ruptura social.

Cursei a Escola Normal em Santos, numa atmosfera social e política muito tensa. Estávamos em 1964 e, em abril, a cidade teve o porto sob intervenção federal e foi duramente atingida pela repressão policial. $\bigcirc$ golpe militar amordaçou a liberdade de organização social. A democracia não existia mais, e as condições nas quais eu havia crescido se findaram. Tinha início uma nova era.

No ano seguinte, quando me mudei para Santo André, comecei a ensinar numa escolinha rural. A escola de prédio rústico, com apenas uma sala de aula, situava-se na vizinha cidade de Mauá, distante um quilômetro e meio do ponto de ônibus mais próximo, trajeto que eu fazia a pé, em meio a terrenos baldios. Ministrava aulas para alunos de três séries numa única turma e pude perceber o quanto minha formação era distante das condições e dos problemas reais que começava a enfrentar. A diferença entre a realidade dos meus alunos e a dos que haviam sido referidos no meu aprendizado de normalista eram enormes, e percebi, como professora, o quanto era inadequada a minha formação para aquelas condições precárias de ensino. Havia muito a ensinar e muito a aprender.

A realidade era perversa, jamais vira tanta precariedade nem convivera com tamanha feiura. A paisagem não lembrava as cidades do interior que, naquela época, guardavam harmonia, e nem tinha semelhança com as de beira-mar ou as do sul do país. O que era muito feio e metia medo não surgia da pobreza, mas do caráter predatório da riqueza que ali se acumulava e se concentrava. A falta de arruamentos e de coleta de lixo, o esgoto a céu aberto, a mistura improvisada de atividades rurais e industriais e as favelas com casas precárias de madeira ou blocos subiam, perigosamente, as encostas dos morros. A pobreza, a falta de higiene e as doenças das crianças se associavam às precárias condições da escola, compondo um triste quadro para a educação. A consciência dos problemas do país entrava em minha mente pelos sentidos, mas principalmente, 
pela falta de sentido do que eu vivia e que se apresentava como carências sociais na minha prática de educadora. Eu estava imersa numa realidade atroz que me angustiava aos 19 anos, mas considerava essa realidade algo em que eu poderia intervir. Lembrava-me de meu primeiro personagem da história, que havia me parecido próximo e como um modelo de homem comum. Deveria, com meu conhecimento, participar ativamente para mudar meu país, contribuindo para superar essa regressão social e urbana que a industrialização predatória trazia.

Em 1966, resolvi fazer o cursinho do grêmio da Faculdade de Filosofia, Letras e Ciências Humanas da USP, que na época ficava em Higienópolis, na rua Albuquerque Lins. $\bigcirc$ ambiente cultural, hoje ausente dos cursinhos em nome da competitividade no vestibular, me aproximou da literatura, do cinema e das artes. A consciência do retrocesso político em que vivíamos, a não conivência com a supressão dos direitos constitucionais e com a dissolução dos partidos políticos, a crítica e a descrença nos discursos oficiais me conduziram a participar dos movimentos de oposição e das passeatas. Jovem intrépida, não temia a repressão e o enfrentamento policial. Passeatas com corre-corre, em razão do lançamento de bombas de gás lacrimogêneo, me intimidavam, mas não chegavam a arrefecer minha vontade de exigir mudanças.

Numa das passeatas de setembro de 1966 - depois conhecidas como setembradas -, no Largo da Concórdia, os cassetetes me alcançaram e, com outros estudantes, fui conduzida pelos policiais militares a entrar num ônibus que nos levou ao Departamento de Ordem Política e Social (Dops) para uma triagem política. $\bigcirc$ acontecimento seria esquecido e teria tido importância passageira, porque lá permaneci apenas vinte e quatro horas, se dez anos mais tarde esse fato isolado não tivesse tido um desdobramento sério em minha vida profissional. Na minha primeira oportunidade de exercer a profissão de geógrafa e trabalhar em órgão de planejamento de governo, fui dispensada. Em Brasília, após todos os trâmites necessários e três dias de trabalho num organismo de planejamento, perdi o emprego que não cheguei a ter, porque meu atestado de antecedentes ideológicos não havia sido aprovado pelo Serviço Nacional de Inteligência (SNI). Tolhia-se uma aspiração, limitava-se o exercício profissional impedindo meu ingresso na profissão, matava-se um projeto.

Após a setembrada, pinço do passado a lembrança das emoções vividas e vejo que minha inscrição no vestibular já não me interessava, uma vez que desejava dar um sentido mais contundente a minha ação. Passei outubro indecisa e em novembro não voltei a frequentar as aulas do cursinho. A difícil experiência de escolher me levou a acreditar que eu poderia ser mais útil me dedicando à formação de quem quisesse aprender, ensinando alunos, crianças, adultos e pais e mesmo participando da vida daquelas pessoas e lugares. Estava vivendo o destino que minha geração me havia reservado, com um sentido de emancipação, de luta democrática e de utopia. Mas esse sentimento de ser útil se associava a muitas indagações que persistiam e que não encontravam respostas. Foi essa busca por respostas potentes e não ilusórias, que não emergem do senso comum, que me fizeram chegar à USP em 1972, quando passei a ser aluna da Geografia. Vivíamos os efeitos do "milagre econômico" que, com seu binômio segurança e desenvolvimento, dava respaldo ao governo dos militares, que recrudesciam a repressão e proclamavam, como se uma ordem fosse, o slogan: Ame o Brasil ou deixe-o.

Em junho soube que o fato de ser professora primária efetiva me permitiria pleitear comissionamento para frequentar o curso de Geografia, dispensada, portanto, de ministrar as aulas, desde que a nota obtida no vestibular estivesse entre as 15 primeiras dos estudantes da faculdade que também 
eram professores primários efetivos. Isso significa o conjunto dos cursos da faculdade: Letras, Ciências Sociais, Filosofia, História e Geografia. Essa normativa remonta aos primeiros anos da USP, concebida como uma universidade nascida na confluência de duas concepções de universidade. A primeira, relativa à concepção de universidade de Wilhelm von Humboldt (irmão de Alexander von Humboldt), fundador da Universidade de Berlim, que entende a universidade como fundamentalmente autônoma, sendo uma instituição de pesquisa e ensino cujo papel não se reduz ao desenvolvimento de uma aptidão, mas deve ser o de prover uma formação ampla e não reducionista. A segunda diz respeito à concepção napoleônica, que vê a universidade como formadora de quadros para o Estado.

Como as questões que envolvem legislações são, tradicionalmente, de lenta solução e como elas sobrevivem aos fatos que as concebem, fui beneficiada por uma normativa que persistia num contexto completamente diferente daquele em que fora gerada. Não havia mais vagas ociosas na faculdade, muito pelo contrário. E já havia os cursos noturnos que permitiam acesso aos que trabalhavam.

Sob essas duas inspirações presentes na gênese da faculdade, desenvolvi meus estudos. A faculdade já não era a mesma de sua origem e nem ficava mais no histórico prédio da rua Maria Antônia, número 258. Até chegar a esse edifício, em 1947, a faculdade permanecera dispersa em vários locais da cidade, contrariando a intenção expressa no ato de sua fundação, que era de reunir suas partes, seus fragmentos num único prédio, com o objetivo de propiciar um bom ambiente para a vida universitária. Esse ambiente foi proporcionado pela Maria Antônia, em função do convívio criativo dos alunos com seus mestres.

No início, a Faculdade de Ciências e Letras reunia sete cursos, sendo a Geografia um deles. Posteriormente, somara-se a eles outros campos do conhecimento. Nos idos de 1969, na esteira da irrupção dos estudantes em 1968, a faculdade foi organicamente desmembrada e o Departamento de Geografia transferido para um dos primeiros prédios que acabavam de ser construídos na Cidade Universitária. Extinguiram-se as cátedras vitalícias, o olhar que se dirigia à França se voltou para os EUA, surgiram as disciplinas semestrais e os créditos por disciplina e se repensou a pós-graduação. Essas mudanças foram concomitantes à mais escancarada repressão, mas não minaram o espírito crítico da faculdade, apenas amordaçaram-na com exilios, aposentadorias e açaimos.

Durante a graduação, vivi, como vivo e viverei, a tensão que é imanente ao ensino público, a tensão entre a universidade e o Estado, cuja relação de dependência implica uma equação difícil: a universidade deve servir aos fins do Estado e, ao mesmo tempo, precisa ser livre e autônoma para cumprir suas próprias finalidades de alcance mais geral.

Minha geração não chegou a ter contato direto com os professores das missões francesa e italiana e nem com outros professores estrangeiros que aqui estiveram na época da fundação da faculdade, com exceção de Pierre Monbeig, que anos mais tarde viria a conhecer em Paris. Fui aluna de muito dos discípulos de Pierre Deffontaines, Pierre Monbeig, Ferdinand P. Braudel, Claude Lévi-Strauss e Roger Bastide.

Na graduação, vivenciei o entrevero acadêmico de três vertentes da geografia como ciência: a da geografia na tradição dos mestres franceses, que me abriu os olhos para a dimensão da história, graças ao historicismo que eles abraçavam; a da chamada geografia quantitativa, que se assumia como salvaguarda da cientificidade; e a da geografia marxista, que ensaiava seus primeiros passos e que teve no departamento seu mais importante centro irradiador. 
Minha expectativa em relação à geografia quantitativa foi como uma andorinha só: não fez verão. A maioria dos professores não experimentava nenhum encantamento por ela e, assim, fui convidada a navegar por outros mares, muito mais interessantes. Mas, se essa novidade se mostrou pouco proveitosa em si mesma, foi muito importante porque trouxe à baila questões de teoria e método que cada vez mais desafiavam a todos.

Ainda na graduação conheci o trabalho do professor Milton Santos, que retornara ao Brasil após ter ensinado no exterior. Sua leitura da geografia partia de algo novo para nós; ele valorizava a profissão de geógrafo defendendo uma posição intelectual terceiro-mundista e apontando problemas novos de pesquisa e questões teóricas instigantes. Aprendi com ele uma lição decisiva, que se mostra cada vez mais relevante para o geógrafo: a de que a "questão está em saber se queremos limitar-nos a uma maneira fixa de interpretação, isto é, à forma única de raciocínio, ou se nos propomos evoluir juntamente com as mudanças que sobrevêm na superfície do globo" (Santos, 1977, p. 1).

Foi nesses anos de graduação que me iniciei na pesquisa, sem qualquer vinculo com bolsa ou institucionalização dessa, como era na época. $\bigcirc$ engajamento nas pesquisas que se desenvolviam no Departamento se constituía numa ampliação de oportunidades de aprender e isso era o que importava. Desde então passei a viver a experiência da pesquisa científica em sua plenitude, com sua beleza, sua angústia e sua carência de recursos. Também experimentei o enclausuramento que ela demanda, subtraindo-nos do convívio social pela reclusão que a leitura e a reflexão exigem e até por uma certa dose de alienação em relação ao que a mass media impõe à sociedade, fazendo-nos sentir muito diferente dos outros, quando fora do ambiente universitário.

Já no $1^{\circ}$ ano de graduação, ao cursar a disciplina Cartografia II, ministrada pelo professor Vincenzo Raffaelli Bocchichio, fui convidada a participar de sua pesquisa de doutorado. Sob sua orientação, fiz minhas primeiras planilhas de codificação de dados e a leitura de fotos aéreas do bairro da Aclimação, onde também apliquei questionários. Tratava-se de uma tese de caráter metodológico, examinando o coeficiente de similaridade na análise de dados de áreas urbanas pela fotointerpretação. Essa experiência me trouxe o aprendizado em aerofointerpretação de maneira privilegiada graças à atenção particular do professor.

Um outro trabalho feito com o professor Bocchichio foi de análise da declividade e das curvas da Serra do Mar que abriu as portas para o meu interesse em geomorfologia. Havia ficado entusiasmada com o curso de geomorfologia ministrado pelos professores Aziz Ab' Sáber e Adilson Avansi de Abreu. $\bigcirc$ professor Aziz me impressionava com sua habilidade de desenhar na lousa. Em suas mãos, o giz se transformava num delicado pincel e o quadro negro, num espaço emoldurado à espera do artista. Ao gesto do mestre num plano, as linhas traçadas desenhavam formas de relevo que tinham profundidade, apresentavam formas convexas e côncavas, perspectivas diversas, ângulos inusitados e substratos rochosos inimagináveis.

Perdurou cerca de dois anos a convicção de que me dedicaria ao estudo das formas de relevo, não mais que isso. Mas esse encantamento me transformou para sempre. Desde então, eu olhar para uma paisagem nunca mais foi o mesmo. Ao êxtase por sua beleza aparente ou ao amargor por seu desfiguramento natural, se aliam sempre as questões "por que a paisagem assume tal forma" e "quais seriam as forças endógenas e exógenas implicadas em seu modelado". 
Foi em 1974, um ano antes de me formar, que ocorreu a mudança mais importante de minha graduação, influenciando daí em diante a minha vida e relegando à memória o interesse passageiro em me dedicar à geomorfologia. Ela se deu quando cursei a disciplina Geografia das Indústrias, ministrada pela professora Léa Goldenstein. A perspectiva teórica e metodológica dessa disciplina discutia a produção industrial como um processo social e analisava criticamente os custos sociais desse processo. Discutimos textos de Thomas Ashton, Paul Baran e Paul Sweezy, Maurice Dobb, Jean Chardonnet, Gunter Frank, Paul Singer, Celso Furtado, Pierre George, Raymond Guglielmo, Warren Dean, José Carlos Pereira e Yves Lacoste.

Fazer uma Geografia que discutia a produção, falava em classes sociais e não em população, incorporava a história e interpretava processos examinando contradições rompia com a tradição lablachiana dos estudos geográficos e negava de pronto a perspectiva do positivismo lógico nessa área do conhecimento. Essa geografia reluzia, era como um ponto luminoso atraente no emaranhado da encruzilhada de perspectivas teóricas e metodológicas que nós, alunos, estávamos confrontando.

Sob a atração desse foco cintilante, o momento exigia outras leituras além das geográficas, como subsídio à abordagem que eu intuía e gostaria de assumir. Foi assim que me dediquei a estudar textos de sociologia, história, política e economia. $\bigcirc$ afã de conhecer era tanto que, paralelamente às disciplinas "oficiais", organizamos com algumas colegas grupos de estudos para ler Celso Furtado, Leôncio Basbaum, Lênin e textos de crítica às teorias da população, particularmente de negação do malthusianismo. Como um ato de liberdade, a dedicação a essas leituras indicava a necessidade de desenvolver uma nova maneira de fazer geografia. Ironia da história: em plenos anos de chumbo, o pensamento marxista chegava à geografia.

Esse novo situar no campo da geografia, cada vez mais compreendida como uma ciência humana e a nova maneira de interpretar a realidade vieram esclarecer uma série de inquietações que me angustiavam desde os tempos que eu comecei a lecionar na periferia da região metropolitana de São Paulo. Mas, ao mesmo tempo, trouxeram novas inquietações. Um certo dia, após o término da aula, a professora Lea me fez dois convites. Um deles me tornaria uma das monitoras da disciplina no ano vindouro, o que acabou se estendendo depois a duas outras disciplinas: a de Orientação à Pesquisa e a de Geografia da População. Com isso, me aproximei muito de seu grupo de alunos de pós-graduação, participando de uma série de atividades por eles desenvolvidas: pesquisa de campo, elaboração de questionários, tabulação de dados e seminários de estudos. $\bigcirc$ outro convite era relativo ao desenvolvimento de sua pesquisa de livre-docência. Trabalhei um ano com a professora Léa, e foi com ela que aprendi o sentido da pesquisa universitária e a necessidade do rigor científico em cada passo da busca do conhecimento. Essa aproximação perdurou dez anos, tendo sido a professora Léa quem me encaminhou para a pós-graduação e me orientou no mestrado.

Em 1978 ingressei no mestrado e logo fui indicada para participar de um programa de estágio no Centro de Computação Eletrônica da Reitoria (CCE) da USP. Naquela época este centro tinha um programa inovador que reunia pós-graduandos de diversas áreas da universidade com o objetivo de desenvolver a aplicação dos recursos da computação nas respectivas áreas de conhecimento. Fiz vários cursos de computação e essa experiência significou o aprimoramento no uso da estatística na pesquisa geográfica e na elaboração de diversos programas 
para tratamento de dados. Na época, ainda se usava a perfuração de cartões de oitenta colunas de registro de dados e tínhamos que transportar pesadas caixas de cartões perfurados ou imensos rolos de fita magnética - o que havia de mais avançado, mas nada comparável ao que viria a ser o mundo da microinformática. Assim, adentrei no mundo da informática praticamente em sua era arqueozoica, aprendendo Algol, Fortran e Cobol, linguagens de programação que logo depois se tornariam desnecessárias ao usuário de informática. Nesse estágio, aprendi a pensar em sistemas e gerenciamento de dados e informações para desenvolver programas de computação aplicados à geografia. Em pouco tempo, passaríamos a digitar diretamente no teclado, num ambiente virtual com capacidade de informação e operações cada vez mais surpreendente. Ainda não havia a internet, que mais tarde associaria informática e telecomunicações, numa verdadeira revolução.

Entre as disciplinas que cursei no Departamento de Geografia durante o mestrado, gostaria de destacar a do saudoso professor José Ribeiro de Araújo Filho que, perseguindo as trilhas do seu mestre Pierre Monbeig, desenvolveu o tema O Café e a Organização do Espaço no Brasil. Essa disciplina me permitiu ver que muitos dos conceitos e problemas da urbanização não são relativos apenas às grandes aglomerações urbanas, mas se recolocam historicamente e assumem outras formas. A descoberta levou-me a compreender que o urbano representa uma totalidade muito mais complexa do que o desenvolvimento da grande cidade.

A disciplina que cursei no Departamento de Ciências Sociais, Formação do Estado Brasileiro, ministrada pelo professor Brás José de Araújo, me levou a conceber um trabalho sobre a relação entre política e urbanização. Naquele verão procedi a uma exaustiva coleta de dados na sede do Tribunal Regional Eleitoral de São Paulo. Na época, tinha que coletar os dados por urna e transcrevê-los em folhas quadriculadas para depois perfurar esses números em cartões que seriam lidos por computadores, ao passo que hoje o Tribunal fornece essas informações digitalizadas. Após esse enorme trabalho de coleta de dados, examinei o comportamento dos votos brancos e nulos, procurei analisar as tendências das alianças e coligações partidárias e a evolução eleitoral dos partidos em alguns municípios. A análise revelou que os municípios mais urbanizados tendiam ao rompimento com o conservadorismo e o "coronelismo", que até hoje persistem, mesmo com todas as mudanças havidas no país. $\bigcirc$ que ficou claro é que, à medida que o homem do campo era expulso e lançado nas periferias urbanas, onde se vinculava ao trabalho assalariado, desligava-se do clientelismo rural, mesmo sem criar vínculo efetivo com a vida na cidade. Já nos municípios mais rurais, o comportamento eleitoral continuava conservador e situacionista, havendo uma tendência clara a escolher prefeitos que pertencessem ao partido do governador.

Se em 1974 o contato com a professora Léa significou uma mudança fundamental de rumo, 1978 seria o segundo momento mais importante da minha trajetória intelectual, influenciando-me teórica e metodologicamente. Naquele ano, cursei a disciplina do professor José de Souza Martins, Sociologia da Sociedade Agrária, também esta do Departamento de Ciências Sociais. Tratava-se inicialmente de uma disciplina do programa de pós-graduação, como qualquer outra da faculdade, com duração de um semestre. No entanto, ao final do período, a disciplina não se concluiu; seu término foi apenas formal, quase simbólico, em resposta à necessidade de avaliação e apresentação de trabalho semestral. Na verdade, ela perdurou 15 anos e, ao longo desse tempo, muitos dos alunos se tornaram professores em diferentes unidades da USP. De fato, era um espaço de discussão de leituras sistematizadas onde o que valia não era 
o mérito de uma aprovação ou o benefício de uma bolsa de estudos, mas o conhecimento. Foi um privilégio que tive, em termos de repensar a ciência e o método do conhecimento científico. Esses 15 anos trouxeram grande enriquecimento intelectual, troca intelectual constante, construção de referências teóricas e profundo convívio universitário, no qual estiveram presentes estudiosos com as mais diversas formações: geógrafos, cientistas sociais, pedagogos, economistas, padres, arquitetos, engenheiros, médicos e advogados, por exemplo.

A proposta do professor Martins era fazer uma leitura metodológica da obra de Marx. Longe de significar ler mais uma vez $O$ capital, o objetivo era, segundo suas próprias palavras, "produzir uma compreensão rigorosamente acadêmica da ampla riqueza dos procedimentos metodológicos de Marx em suas diferentes obras". Essa preocupação do professor Martins decorria de sua negação da leitura estruturalista, sempre associada ao evolucionismo mecânico, que vinha seguido de leituras ideologizadas do marxismo, que invadiam e, em seu simplismo reducionista, assolapavam o trabalho universitário.

A primeira obra de Marx que li foi Elementos fundamentais para a crítica da economia política (Grundisse). Quanto a O capital, li e reli em duas edições diferentes. Estudamos o Capítulo inédito, a Teoria da mais-valia, a primeira parte de A ideologia alemã - obra em coautoria com Engels -, a Contribuição à crítica da economia política, os Manuscritos econômicos e filosóficos, a Questão judaica e A miséria da filosofia, sempre preocupados com o rigor do método.

Depois de dez anos de estudo dos textos de Marx, em 1988, o professor Martins sugeriu que abordássemos a obra de Henri Lefebvre, autor que analisa a sociedade contemporânea. Como renovador do pensamento de Marx, Lefebvre considera que a continuidade da dialética, no século XX e no fim deste milênio, como instrumento de produção de conhecimento científico, não se confunde com a repetição de Marx, em muitos aspectos um autor do século XIX (Martins, 1996). Discutimos várias obras lefebvreanas. Lemos os quatro volumes de De L'État, Le Retour de la Dialectique, Une Pensée Devenue Monde: Faut-il Abandonner Marx?, Hegel, Marx e Nietzsche ou Le Royane des Ombres, Metaphilosophie, Sociologie de Marx, Au-delà du Structuralisme, Logique Formelle, Logique Dialectique e os três volumes de La critique de la vie quotidienne. Entre essas obras, tiveram um significado particular para mim Le Manifeste Différencialiste, La Presencia y la Ausencia e La Conscience Mystifiée, sendo a última uma obra em coautoria com Norberto Guterman.

Embora o grupo envolvido nessas leituras tivesse como norma não comentar nos seminários as pesquisas individuais, atendo-se exclusivamente aos textos em discussão, a qualidade intelectual desse trabalho universitário, realizado fora de todas as regras estabelecidas, marcou definitivamente a produção individual de todos os que dele participaram. Ao final dos longos anos em que nos reuníamos às sextas-feiras pela manhã, semestre sim, semestre não, deixei de participar do seminário final e do projeto do livro Henri Lefebure e o retorno à dialética. Nesse semestre, estava em viagem no exterior, procedendo à minha pesquisa de pós-doutorado, e não pude acompanhar esse fecho do que intimamente chamávamos de "seminário do grupo do Martins".

Durante o período do mestrado, que perdurou até 1985, compartilhei com vários colegas da pós-graduação da preocupação em renovar os estudos em geografia e as dúvidas como encaminhar uma análise dialética do espaço. Foi com essa preocupação que retomei e ampliei os estudos com minha colega e amiga Ana Fani Alessandri Carlos sobre a história do pensamento geográfico. Es- 
ses estudos visavam apreender as categorias de análise da geografia que adotavam autores clássicos como Maurice Le Lannou ou Jean Brunhes, de captar o que elas esclareciam e que outras categorias de análise poderiam ser incorporadas ao pensamento geográfico, potenciando instrumentos que revelassem as contradições da relação sociedade-espaço. Como resultado desses estudos conjuntos, escrevemos três textos que foram apresentados em reuniões científicas e depois publicados. A esses textos se somaria mais um, que são nossas únicas coautorias. Como prática do nosso Programa de Pós-Graduação em Geografia Humana, enfatizamos e privilegiamos a autoria única e não assinamos artigos com orientandos, mesmo que sejam produtos de dissertações e teses que orientamos e que sejam textos revistos e completados por nós. Ser professor e orientador é, acima de tudo, ser generoso no compartilhar de experiências.

Com essa colega foi com que compartilhei muitas dúvidas teóricas acerca da apropriação capitalista do espaço, buscando incorporar a dimensão do valor de troca e da renda da terra na análise do espaço. Naquele início de década, essa preocupação respondia ao desejo de renovar criticamente a perspectiva geográfica, especialmente o enfoque dos estudos em geografia urbana e regional, o que, de fato, minha geração faria.

Tornava-se claro que o espaço tinha suas especificidades, não se constituindo como uma mercadoria como outra qualquer. Tratava-se, mais uma vez, do desafio imposto a nós mesmas de levantar elementos teóricos para o estudo urbano e regional na perspectiva geográfica e, de uma maneira geral, de uma tentativa de superar impasses e dilemas sobre o que se discutia como crise da geografia. A nosso ver, a crise da geografia decorria também do uso indevido e reduzido do conhecimento de outras disciplinas em que ela procurava se apoiar na elaboração de novas análises. Era fácil encontrar reduções teóricas absurdas e equivocadas que vulgarizavam o conhecimento.

Nessa fase de formação, de profunda preocupação teórica e metodológica, ficava cada vez mais claro para mim que o sentido que eu buscava para a geografia era sobretudo o da possibilidade de compreender as desigualdades espaciais.

Em 1982, terminaram meu estágio no CCE e meu afastamento como professora e eu voltei a lecionar no ensino médio. Mas vivi também outras experiências acadêmicas, como a do Instituto de Estudos Econômicos de São Paulo (Idesp), com o professor Bolívar Lamounier, que na época lecionava na Pontifícia Universidade Católica (PUC), tendo muitos anos depois vindo para nossa faculdade, para o departamento de Ciências Sociais. Minha participação na pesquisa do instituto dizia respeito à análise da dispersão e concentração territorial dos votos dos deputados estaduais eleitos em 1982, relacionando essa análise com os padrões regionais de desenvolvimento urbano no estado de São Paulo.

Também participei de outra pesquisa que era vinculada à Fundação de Pesquisa Ambiental (Fupam), coordenada pelo professor Philip Gunn, da Faculdade de Arquitetura e Urbanismo da Universidade de São Paulo (Fauusp), e seu título era: Mecanismos de intervenção governamental na evolução da rede urbana paulista. Minha inserção nessa pesquisa estava voltada para a análise da rede urbana paulista.

Participava também das reuniões do Núcleo de Estudos Regional e Urbano (Neru), da revista Espaço E Debates, cujo corpo editorial eu integrava. Essa revista havia sido concebida no ano anterior por um grupo de professores, profissionais e pesquisadores estudiosos das questões urbanas e regionais. Nessas reuniões, buscávamos nos atualizar sobre temas e questões relativas à análise 
regional e à intervenção urbana. Por meio da revista Espaço E Debates, de acordo com sua proposta editorial (1981, p. 5), buscávamos "contribuir para a compreensão e identificação dos componentes envolvidos nas dinâmicas econômica, política e ideológica que norteiam as diferentes formas e conteúdos de intervenção no espaço".

Esse foi o contexto que me conduziu a traduzir, junto com o professor Philip, um texto de Doreen Massey acerca do regionalismo, no qual essa geógrafa inglesa desenvolve uma discussão marcante sobre a questão da desigualdade regional. Essa foi minha primeira contribuição nesse periódico; depois, publiquei artigo e resenhas de geógrafos e até hoje mantenho contato com o núcleo da revista, algumas vezes fazendo parte de seu corpo editorial, outras apenas dando pareceres sobre artigos enviados à revista para publicação.

Em novembro de 1982, ingressei como professora no Departamento de Geografia, após um processo de seleção que constava de prova escrita, aula didática e entrevista para preenchimento de uma vaga na área de Geografia Regional. Sendo meu contrato como docente de tempo parcial, tive de interromper minha participação nas pesquisas do Idesp e da Fupam, já que não poderia deixar meu trabalho de professora de nível médio, fundamento de minha remuneração na época.

Ingressei como Auxiliar de Ensino, apenas como bacharel e licenciada em geografia. Lecionei com a professora Maria Regina de Toledo Sader, que voltava de longo exílio na França e se inseria novamente no departamento. A turma tinha 90 alunos; número alto, mas não tanto quanto o de outras turmas. Nesse início de docência universitária, tratava-se de reafirmar minha condição de professora, que consistia em aprender transmitindo conhecimento e ensinar com responsabilidade pela formação da consciência do outro.

Minha preocupação com o estudo regional levou a compartilhar mais uma vez com minha colega e amiga Ana Fani Alessandri Carlos as preocupações teóricas em relação à geografia, que nos conduziu a investigar como que o "regional" era discutido no Boletim Paulista de Geografia. Analisamos todos os textos publicados como estudos regionais, além dos editoriais do periódico. Pudemos perceber claramente, nos estudos regionais, a reiterada manifestação da influência da escola lablachiana nos primeiros 13 anos do periódico, como também a falta de uma reflexão teórica sobre região, que só aparecia no artigo de Pierre George publicado em 1963. Notamos que havia poucos artigos relativos à geografia quantitativa e identificamos seus autores como os da "Escola de Rio Claro". Percebemos também a grande mudança no Boletim havida em 1973, dada a influência do marxismo na geografia, que introduziu novos temas e colocou o estudo regional em um plano secundário. Em outros termos, a emergência e o aflorar das questões metodológicas em debate indicavam, claramente, que a geografia passava por uma renovação. Nós vivíamos intensamente essa turbulência e buscávamos construir alternativas.

A situação que vivia era dilaceradora, pois as obrigações com o ensino médio e o apaixonado engajamento como docente do Departamento, envolvida, como auxiliar de ensino, em preparação de aulas, correção de trabalhos e provas, acompanhamento de alunos, excursões e comissões, enfim, do que é próprio da carreira docente, aliados às atividades da pesquisa de mestrado que exigiam viagens para o interior do estado estreitavam as vinte quatro horas do dia. Parece que elas nunca mais retornaram a sua dimensão devida e, daí em diante, se adelgariam progressivamente. 
tema da minha pesquisa de mestrado dizia respeito ao estudo da relação entre agricultura e urbanização e como estudo de caso a referência foi a cidade de Jardinópolis, uma pequena cidade. Sempre havia me chamado atenção o fato das pequenas cidades serem extremamente semelhantes em aparência, aspecto que, no entanto, não resistia a um olhar mais acurado, que trazia à tona as diferenças. E isso me intrigava tanto quanto o fato de umas cidades terem crescimento rápido, enquanto outras estagnavam.

Além disso, percebia que quase não havia estudos sobre pequenas cidades, talvez porque muitos deles no passado fossem apenas monótonas monografias e expressassem, muitas vezes, o típico modelo de uma investigação que repetia a mesmice. Além disso, considerava que a prioridade quase absoluta dada ao estudo da indústria e da urbanização levava a uma descabida desconsideração de um número enorme de cidades no estado de São Paulo, para não dizer do Brasil, e, também, intuía que o estudo das pequenas cidades traria elementos novos e fundamentais para se conhecer o processo de urbanização, já que esse não produz apenas grandes cidades ou metrópoles. Estava vigente uma dicotomia entre a urbanização de cidades do interior e a da metrópole, que a meu ver essa segmentação dualista se mostrava falsa.

Participaram como banca de minha de defesa pública, além da professora Léa, que presidia a sessão, os professores José Graziano da Silva, da Universidade Estadual de Campinas (Unicamp), e o professor Pasquale Petrone, que me atribuíram nota dez com distinção. Com a apresentação da dissertação Agricultura e urbanização - a capitalização do campo e a transformação da cidade: Jardinópolis, o estudo de um lugar, o título de mestre alçava-me à condição de poder ser responsável por disciplinas no Departamento. Estávamos em 1985, e não só a conclusão do longo trabalho de mestrado significava mudanças. Igualmente importante foi a mudança do meu regime de trabalho na universidade, que passou a ser de tempo integral, possibilitando-me dedicação exclusiva à vida universitária. Também o rumo do país mudava significativamente. Nesse ano, a direção política do país, desde 1964 nas mãos dos militares, passava aos civis, graças ao movimento social e ao resultado de votação no Colégio Eleitoral. A República ressurgia, a amplitude das mudanças trazia regozijo coletivo e novos sonhos eram construídos.

A década de 1980 significou transições importantes e amplas na política brasileira. De diversas maneiras concorreram para mudanças na vida social e interferiram na vida universitária, na Faculdade de Filosofia, Letras e Ciências Humanas, no Departamento de Geografia e na própria maneira de orientar a formação do geógrafo. Foi nessa década que o governo estadual restituiu o prédio da Maria Antônia, edifício símbolo da resistência da faculdade à supressão da democracia, da luta pela liberdade de ideias e do combate à ditadura. Reintegrava-se ao patrimônio da universidade e se colocava a serviço da cultura reconstruindo laços com a cidade, representando novos tempos e inaugurando novas esperanças.

Foi esse o contexto em que iniciei o doutorado sob a orientação da professora Maria Adélia A. de Souza, etapa que conclui seis anos mais tarde, com Ana Fani Alessandri Carlos. Passei a me dedicar, entre as disciplinas da área de regional, à disciplina intitulada Iniciação à Pesquisa, que muito contribuiu para me ensinar a orientar.

Naquela época me fazia todos os dias a seguinte questão: desde quando se pode, no Brasil, falar em região como uma questão do Estado nacional? Em outros termos, a partir de que momento se poderia falar em região e questão regional no Brasil? Por meio de leituras 
acerca da história brasileira, observei que o Brasil apresenta questões que poderíamos chamar de regionais já no momento da internalização física e territorial do poder metropolitano em 1808, momento em que o Brasil passa a se constituir, pela primeira vez, num território referenciado internamente. Mais uma particularidade do país: a de apresentar uma questão regional sem um Estado constituído. Para essa reflexão tomei como referência a Revolta dos Balaios, maior movimento regional do Império brasileiro ocorrido no Maranhão, tendo, inclusive mapeado os campos de batalha comparando o mapa do Maranhão e do Piauí, de 1868, com os mapas atuais, permitindo circunscrever a região do conflito. Concluí essa pesquisa convicta de que a Revolta dos Balaios, ao se constituir em plena Regência como uma problemática de caráter territorial, colocou-se como uma importante questão regional na medida em que muitas das reivindicações se revestiram de manifestações de cunho territorial, expressas na luta pelo poder local e pela redução do poder central do Império.

Ao ler esse trabalho, o professor Manuel Correia de Andrade, me escreveu dizendo: "tive a oportunidade de ler e reler seu trabalho sobre a Balaiada, n uma linha que muito me agrada por ser totalizante, dominando conceitos arbitrariamente classificados como de História, de Geografia, de Sociologia etc. Considero o mesmo de bom nível, quer quanto a metodologia de exposição, quer quanto ao estilo e é muito oportuno porque traz uma visão nova e uma série de contribuição ao conhecimento da formação do Brasil [...]".

No início do meu programa de doutorado tive oportunidade de fazer um estágio na França, visitando vários laboratórios de pesquisa em geografia, vinculados ao Centre National de la Recherche Scientifique (CNRS). A convite do professor Michel Rochefort, um dos geógrafos e planejadores franceses que mais influenciou os estudos urbanos e regionais no Brasil, e contando com o apoio do Programa de Aperfeiçoamento Científico no Exterior da Fundação de Amparo à Pesquisa do Estado de São Paulo (Fapesp) e do Centre des Relations Exterieures de Cooperation et Développement da França, tive chance de estabelecer contato direto com instituições de governo e centros de pesquisas franceses.

Em Paris, a visita a inúmeras bibliotecas, centros e museus e meu trabalho sistemático de pesquisa bibliográfica, leitura e observação, assim como os seminários e cursos de que participei, aprofundaram questões teóricas sobre a problemática urbana e regional. $\bigcirc$ estudo das cidades e dos chamados problemas regionais se colocava de uma nova forma. $\bigcirc$ desafio consistia em incorporar criticamente toda essa pesquisa bibliográfica feita nas melhores fontes francesas, em conhecimento organizado para a análise da realidade brasileira, particularmente, de questões que eu levaria adiante no doutorado. Foi nessa viagem, que tive a oportunidade de entrevistar o professor Pierre Monbeig, cujos trabalhos muito me haviam influenciado.

Próximo ao Jardim de Luxemburgo, no Quartier Latin, o professor Pierre Monbeig me recebeu várias vezes em sua residência, indicando livros, lugares, pessoas e centros de pesquisa que considerava importantes para o meu conhecimento. Sob um frio rigoroso até mesmo para os parisienses, o professor me recebia com uma boina típica de montagnard e cachecol de lã e, gentilmente, providenciava um cafezinho. Perguntava acerca de meu trabalho, mostrava gostar de me ouvir e dizia já não saber falar o português - o que não era verdade. Afirmava não mais conhecer o Brasil e mostrava sua atual preocupação, repetindo várias vezes: "Madame, a Amazônia, a Amazônia...". 
Junto ao professor Michel Rochefort, tive todo o apoio para meu trabalho no Instituto de Geografia e, por sua recomendação, me foram abertas as portas de diversas instituições, bibliotecas, universidades e centros de pesquisa. Entre os vários cursos e seminários de que participei, o contato com o professor Paul Claval concorreu para mostrar a importância de se incorporar à análise geográfica a dimensão cultural.

Fora de Paris, visitei centros de pesquisa em Bordeaux e Toulouse. A partir desse estágio na França pude perceber a real importância da cooperação científica e do intercâmbio acadêmico internacional no sentido de acelerar, intensificar e atualizar o debate das questões da geografia.

Logo que retornei, a Coordenadoria de Estudos e Normas Pedagógicas (Cenp), órgão da Secretaria de Educação, pediu-me uma assessoria para elaborar a Proposta Curricular para o Ensino de Geografia de Primeiro Grau, particularmente da $1^{\mathrm{a}}$ à $5^{\mathrm{a}}$ séries (hoje $2^{\circ}$ a $6^{\circ}$ ano do ensino fundamental), graças a minha experiência no curso primário. Esse trabalho foi muito interessante e, durante todo o seu desenvolvimento, lembrei da minha atuação como professora primária e das difíceis condições de trabalho que enfrentava.

Em 1988 embarquei novamente para a Europa com apoio da Fapesp, para participar de reunião internacional. Era o meu primeiro congresso científico no exterior, em Amsterdã. Tratava-se do $46^{\circ}$ Congresso Internacional de Americanistas, congresso que participo até hoje. $\bigcirc$ trabalho apresentado se situava como um desdobramento da reflexão que desenvolvi na dissertação de mestrado e, posteriormente, o organizador daquela sessão de debates me escreveu propondo que eu atualizasse informações e elaborasse mapas com o intuito de publicá-lo. Em 1995, esse trabalho surgiu sob o título "Rural Transformation and Urbanization in a Core Region: The Historical Development of Rural-Urban Relations in the State of São Paulo, Brasil", capítulo do livro Regional Development in Latin America, da série latino-americana publicada pela editora Thela, de Amsterdã.

Ainda no ano de 1988 me associei à International Sociological Association e participei no Rio de Janeiro da reunião do Comitê de Sociologia do Desenvolvimento Urbano e Regional. Nessa reunião, tive contato com a pesquisa de Mark Gottdiener, então professor de sociologia e coordenador do programa de Estudos Urbanos da Universidade da Califórnia, em Riverside, nos EUA. A originalidade dos trabalhos de Gottdiener, situando-se numa perspectiva critica dos principais teóricos do urbano, privilegiava o enfoque da produção social do espaço urbano. Indiquei à Edusp a tradução do seu livro, que veio a público em 1993.

O ano seguinte marca uma nova inflexão na vida institucional da universidade. Trata-se da autonomia universitária que, entre outras coisas, atrela o orçamento da universidade ao recolhimento do ICMS, cabendo às universidades paulistas 9,57\% do valor arrecadado anualmente e à USP, 5,20\% dessa porcentagem. Isso não muda a difícil tarefa de levar adiante uma universidade que requer vultosos investimentos para garantir sua excelência acadêmica no desenvolvimento do ensino, da pesquisa e da extensão. Como as demais universidades públicas, ela exige recursos significativos para cumprir seus objetivos. Mesmo nos EUA, em cujo ensino superior predominam as instituições privadas, mais da metade dos recursos provém do setor público.

Durante o doutorado, simultâneo à docência no Departamento, comecei a participar mais frequentemente de atividades acadêmicas no exterior e intensifiquei minha participação em pesquisas. Desenvolvi três projetos de pesquisa que contaram com o apoio do Conselho 
Nacional de Desenvolvimento Científico e Tecnológico (CNPq). $\bigcirc$ objetivo desses projetos era desenvolver matrizes teóricas e um banco de dados para a elaboração de minha tese de doutorado, mas seus resultados foram além disso. A combinação dessas diferentes pesquisas foi extremamente estimulante para o andamento e o resultado final da tese, concluída em 1991.

Na dissertação de mestrado, havia analisado a relação entre a agricultura e urbanização, particularmente o desenvolvimento de relações capitalistas no campo e o processo de urbanização paulista que havia conformado a rede urbana estadual e a primazia da cidade de São Paulo como centro hegemônico do país. A década de 1980 revelava sinais de grandes transformações na Região Metropolitana de São Paulo, tanto quanto no interior, que renovava e adensava sua industrialização. Caberia, então, refletir sobre a relação entre indústria e urbanização no sentido de compreender a reestruturação em curso, as transformações regionais do estado de São Paulo e a persistente afirmação da primazia de sua Capital.

Percebia que a temática regional havia deixado de ser o eixo central de legitimação de muitas políticas de desenvolvimento. Afinal, essas políticas haviam muito pouco cumprido seu papel no desenvolvimento regional e significavam apenas a modernização de algumas regiões do país, uma vez que as disparidades regionais, em vez de diminuírem, haviam aumentado no período de maior investimento nos planos de desenvolvimento regionais. Não havia interesse institucional do governo pelo planejamento regional e, ao mesmo tempo, o tema e o estudo da região pareciam perder sua legitimidade teórica. Um fator adicional para o declínio da temática regional procedia do fato de a região se constituir numa noção polissêmica, o que a comprometia como categoria de análise científica. Diante dessas dificuldades, para se manter a legitimidade teórica e científica da noção de região, noção tradicional e tão cara à Geografia, eu considerava que o abandono puro e simples do estudo regional não seria a melhor solução, e que os geógrafos deveriam enfrentar o desafio intelectual de repensar esta noção. Foram essas reflexões que me inspirou na formulação do tema de minha tese de livre-docência.

Ao mesmo tempo em que investigava esse tema, via crescer o desprestígio da área de geografia regional no Departamento. Como é próprio da academia, esses nem sempre são inspirados por motivos intelectuais, mas pelos abismos da alma humana. A participação em comissões crescia vertiginosamente, mormente após a obtenção do título de doutorado, obtido em 1991. Nessa tese, defendia a ideia de que ao contrário do que aconteceu nos países desenvolvidos, a reestruturação industrial não era decorrente da incorporação de tecnologias ou do desenvolvimento da produção flexível. Mas era um produto da dispersão dos estabelecimentos fabris e da precarização do trabalho associadas aos processos de concentração e centralização do capital que vinham e vêm aprofundado o caráter desigual do desenvolvimento brasileiro. Chamei atenção para o fato de que esses processos se deram num quadro de ampliação da metrópole paulista e desconcentração espacial da produção industrial, negando a perspectiva que entende esse processo como descentralização industrial e afirmando a ideia de que se configurava uma região metropolitana desconcentrada, na qual a cidade de São Paulo se afirma mais e mais como centro. $\bigcirc$ entendimento do processo como sendo de descentralização era hegemônico e capitaneado pelo Instituto de Economia da Unicamp. Anos mais tarde, assumiriam a ideia de desconcentração e rejeitariam a de reversão da polarização, sem contudo nunca ter feito referência à tese ou aos textos de um simples professor da geografia; afinal, tratava-se de uma disciplina "escolar". 
Sua defesa pública ocorreu em 1991, e fui aprovada com a nota 9,5, em banca presidida pela professora Ana Fani Alessandri Carlos, tendo como examinadores o professor Armando Corrêa da Silva, também do Departamento de Geografia, o professor Celso Lamparelli, da Faculdade de Arquitetura e Urbanismo, e o professor Henrique Rattner da Faculdade de Economia e Administração, todos da USP, e do professor Pedro Pinchas Geiger, da Universidade Federal do Rio de Janeiro.

Em todas essas experiências na vida universitária - nas comissões voltadas para a administração das atividades do Departamento, na pesquisa, no ensino e na extensão -, enfrentei obstáculos e surpresas. Muitos obstáculos advieram da minha posição no Departamento, que foi de não alinhamento na disputa pela liderança nos encaminhamentos da vida acadêmica. Fui crítica aos grupos e preferi a posição que me caracteriza: independente, mas participante. Procurando entender a relação entre o discurso e a prática, superei constrangimentos que me foram impostos e busquei superar preconceitos e posições maniqueístas, presentes nessas disputas e na atuação de grupos. Embora uma apreensão superficial da dinâmica entre os colegas pudesse indicar que um dos grupos, por se considerar mais progressista, pairasse acima do bem e do mal, diferentemente de outros, nada disso era, de fato, real. A meu ver, sob o estigma de conservadores ou progressistas, se impuseram à vida universitária no Departamento dilemas e impasses absolutamente desnecessários.

A vida aparecia mais adversa e o cenário se abria às privatizações, ao aniquilamento do protecionismo contra investidas do capital estrangeiro, à desnacionalização de empresas, ao estrangulamento dos gastos públicos, ao arrocho salarial e ao solapamento tênue, que iria se fazer vigoroso mais tarde, dos direitos sociais. A cartilha em voga negava o nacional desenvolvimentismo e se intitulava $O$ Consenso de Washington.

Em 1992, voltei ao Institut de Géographie, da Universidade de Paris I, Pantheon-Sorbonne, para um pós-doutorado com o objetivo de estudar as transformações das regiões metropolitanas procurando novos embasamentos teóricos que poderiam ajudar a compreender o processo que havia percebido em São Paulo.

No retorno à USP, pedi meu credenciamento na pós-graduação para orientar em nível de mestrado, mas obtive aprovação para orientar também doutorandos. Situada em linhas de pesquisa relativas à reestruturação produtiva, ao desenvolvimento regional e à produção do espaço metropolitano, orientei sempre inspirando minha conduta na de meus antigos mestres, procurando desenvolver a iniciativa, a criação e a crítica consistente, que devem pautar o espírito científico.

Compartilhando da posição de Florestan Fernandes, de que a universidade deve preparar o desenvolvimento de uma consciência autônoma e apurada do cidadão, nunca sugeri temas de trabalho, pois eles devem emanar do interesse e da curiosidade que levam o pesquisador à descoberta, e seu grau de relevância e pertinência é em si componente da formação de pesquisador. Muitas vezes, a indefinição e demora na escolha do tema são angustiantes, mas parecem ser um aprendizado indispensável. Futuramente, muitos desses alunos estarão não só fazendo outras pesquisas, mas também acompanhando a pesquisa de outros, com orientadores, sem supervisão, e devem ser capazes de fazer escolhas. Nesse sentido, só podem emancipar a outros se na orientação recebida tiverem aprendido o sentido do conhecimento emancipacionista, que orienta, instiga a crítica e desenvolve potencialidades sem aprisionar consciências. 
Não poderia deixar de fazer esta observação: o que se busca é desenvolver uma orientação que não se traduz em fazer da pesquisa do pós-graduando o meu projeto nem impor a ele um aspecto do meu projeto de pesquisa. Não cabe instrumentalizar a relação com o orientando, nem torná-la funcional para o orientador, sob pena de tolher iniciativas e reduzir a possibilidade de formar verdadeiros pesquisadores. Toda arte está em transitar por esse caminho sem produzir excessos, pois todo excesso é prejudicial; o da luz obscurece e o de ver exclusivamente a si mesmo impossibilita o diálogo, ao passo que o excesso de insegurança realça as dúvidas e torna permanente o indefinido. Desse modo, impossibilita-se o desenvolvimento de qualquer projeto.

desafio de refinar temas amplos sem perder a totalidade, o aprendizado em circunscrever o tema, o exercício metodológico na construção do objeto de pesquisa, na problematização e na elaboração de hipóteses se constituem nos momentos mais instigantes de qualquer projeto de pesquisa. Fazê-los compreender que a pesquisa não constitui um fim em si mesmo, sendo ela um instrumento da ciência, não é difícil. No entanto, fazê-los compreender que um problema da realidade não se confunde com um problema do conhecimento e que o objeto de pesquisa é uma construção intelectual, não podendo ser confundido com coisa ou lugar, por mais relevantes que sejam, é tarefa bastante árdua.

Cada vez mais passei a apresentar os resultados de minhas pesquisas em congressos e a viajar para a Europa com mais frequência. Tornava-se cada vez mais claro para mim que diante da velocidade e profundidade das transformações da vida atual, cada vez mais a ciência contemporânea requer precisão e urgência na elaboração de respostas. Pensando o hoje, voltei aos clássicos, e a leitura crítica de Bernard Kayser me deu a chave para discutir espaços metropolizados e não metropolizados. Permitiu pensar que existem espaços que, embora não estejam na região metropolitana, têm algumas características próprias da metrópole, que, até então, só eram encontradas na metrópole, por exemplo, as empresas de auditoria. Denominei-os espaços metropolizados, em contraposição aos não metropolizados.

Em 1996, fui convidada por colegas de outra unidade para participar de um projeto temático apoiado pela Fapesp intitulado São Paulo: globalização da economia e impactos na estrutura, que discutia se São Paulo era uma cidade global. Contou ainda com a participação de outras unidades da USP - a Escola Politécnica e a Faculdade de Economia e Administração - e congregou pesquisadores estrangeiros, cabendo destacar, pelo seu renome, a socióloga Saskia Sassen, professora da Universidade de Columbia em Nova York. Como corolário, se publicou o livro Globalização e estrutura urbana.

O envolvimento com a disciplina Teoria da Região e Regionalização e com as pesquisas voltadas para a discussão da expansão da Região Metropolitana de São Paulo, se desenvolveram num contexto de muitas indagações sobre a relação entre região e geografia. Exigiram um exaustivo levantamento bibliográfico sobre a noção de região, num universo de referências bastante disperso. Essa preocupação se dava num contexto que já comentei, de desvalorização da temática regional no meu Departamento que, anteriormente, havia abrigado pesquisas com essa perspectiva analítica, que se tornaram clássicas. Mas, concomitante a essa situação de desprestígio, a realidade apontava a emergência de novos e velhos regionalismos, que se revelavam com força total. Ao mesmo tempo, outras disciplinas inseriam-se no debate. Embora 
a região parecesse um tema fora de moda entre os geógrafos do meu Departamento, ela não estava fora de moda na nova geografia do mundo e nem mesmo estava ausente da formulação de propostas para o Brasil, pois a questão regional é parte constitutiva de um projeto nacional.

Minha tese de livre-docência, apresentada em 1997, é sobre esse tema, e grande parte dela inspirou a publicação de meu livro Região e Geografia. Para a obtenção desse título, apresentei uma tese, claro, elaborada sem qualquer supervisão, me submeti a uma prova escrita, aula didática e arguição de Memorial, como é comum em concursos de ingresso. A banca é composta por cinco arguidores, e os exames duram de três a quatro dias. Já não fiz a prova prática, que havia sido eliminada pelo Regimento da Faculdade. Participaram de minha banca o presidente, Adilson Avansi de Abreu, professor do Departamento de Geografia ao qual pertenço; o professor Pasquale Petrone, do mesmo Departamento; o professor Murilo Marx, da Fauusp; o professor Manoel Correia de Andrade, da Universidade Federal de Pernambuco, e professor Jurgen Langenbuch, da Unesp, campus de Rio Claro. As apreciações desse trabalho e das provas que compõem o concurso de livre-docência resultaram na nota máxima, 10, com as menções de distinção e louvor.

Esse trabalho se desenvolveu num contexto epistemológico da ciência que enaltecia a técnica e o saber prático em detrimento de outras reflexões. Na medida em que as ciências humanas podem escapar a essa lógica e resistir a ser instrumentalizadas pelo capital, a produção acadêmica da faculdade reafirma o sentido da universidade. Emanada na articulação entre o ensino de uma disciplina e a pesquisa, de certa maneira, minha tese de livre-docência é representativa, no seu sentido mais radical, da perspectiva que Humboldt imprimiu à Universidade de Berlim, em 1820, de que a pesquisa e ensino são indissociáveis.

Era final do século XX e estava claro que as especializações, que fragmentam o saber, são próprias dos fins do século XIX e do XX. A tendência que se afirma na produção do conhecimento vai num sentido inverso, o da integração entre os saberes. $\bigcirc$ que aparece com força, nesse novo século, é a busca por unificar os fragmentos do saber, procurando alcançar um patamar novo da ciência. Não que as especializações verticais tenham perdido sentido, elas continuam fundamentais, mas a elas se acrescenta uma nova forma, contribuindo para a compreensão e a explicação da realidade, pois é a partir da compreensão e da explicação cada vez mais acuradas que podemos equacionar os problemas que temos de resolver. É como se o presente nos dissesse: construam pontes entre os saberes, porque sem elas não poderemos avançar em direção ao futuro.

Parecia conhecer a vida acadêmica, os cursos, a pós-graduação, as comissões da faculdade, os congressos, as publicações, os concursos etc. A vida universitária me ensinaria um aspecto novo, o da crescente participação na gestão universitária, tendo sido assessora de duas Pró-Reitorias, a de Cultura e Extensão e a de Pós-Graduação. As atividades de cultura e extensão, vale destacar, estão na gênese da faculdade, quando o que se tinha eram as "lições públicas" dadas por professores, assistentes e alunos para o público em geral.

É oportuno afirmar que são consideradas atividades de cultura e extensão aquelas indissociáveis do ensino ou da pesquisa. Se não estiverem vinculadas a ambos ou ao menos a um deles, não se constituem em atividades acadêmicas e podem facilmente vizinhar com formas de assistencialismo ou paternalismo, que subvertem a finalidade da universidade. Essas ativi- 
dades inseparáveis do ensino e da pesquisa são um espaço privilegiado da práxis acadêmica e uma possibilidade de democratizar o conhecimento. Essas atividades fazem a universidade transcender a produção do conhecimento e a formação profissional do aluno, situando-se num espaço de disseminação mais amplo do saber acadêmico na sociedade e redimensionando a questão ética e política do conhecimento.

$\bigcirc$ contexto de minha participação na gestão central da universidade, na primeira década do século XXI, deu-se num ambiente de descrença social e de dúvidas acerca das políticas neoliberais, que foram vistas como tábua de salvação no início dos anos 1990. Parecia mais que a sociedade estava agredida pela "mão invisível do mercado", pairando sobre a universidade um certo pessimismo que se prolonga ainda hoje.

ar carregado decorre da consciência de que a universidade está não só desvalorizada, mas ameaçada. Decorre também, da consciência de que, apesar desse esforço, não devemos nos prender aos êxitos passados, e devemos atentar para as mudanças do presente, bem como construí-lo sem comprometer o futuro. Um presente e um futuro que se desenvolvem sob uma nova égide, buscando visibilidade muito mais na transitoriedade da palavra digital do que na transparência da duradoura palavra impressa, já que é aquela que possibilita a expansão e disponibilidade de informações em proporções jamais imaginadas.

Na universidade, a chamada "mão invisível do mercado" cria possibilidades, seduz, estabelece diferenças, propõe desvios e invade de forma sub-reptícia o discurso acadêmico. Nas discussões do Departamento, são cada vez mais frequentes os questionamentos acerca da preparação dos alunos para atuarem no mercado de trabalho, onde os imperativos da técnica e do conhecimento prático representam o que de mais avançado pode ser feito em termos de ciência geográfica. Nada mais concordante com o novo tempo essa angústia em responder ao mercado, na qual facilmente a universidade se confunde com empresa e do conhecimento se faz uma mercadoria.

A meu ver, a pertinência da ação acadêmica não pode ser reduzida a uma questão de mercado. A ela concerne uma teia complexa de elementos, além de ter, necessariamente, a ousadia de se adiantar ao seu tempo. Só uma visão estreita tomaria um dos elementos como único. É indispensável dizer que não se trata de um aspecto qualquer; trata-se do mercado, que se constitui como o verdadeiro oráculo do nosso tempo, que paira onipotente sobre todos, que nos promete os céus, a justiça e a felicidade eterna.

A ideia de mercado está tão presente que a referência a apoios recebidos, por exemplo, para a publicação de um livro ou para participação em congressos, tem sido mencionada como "patrocínio". Antes, a comunidade acadêmica usava o termo 'apoio'. Substituiu-se essa palavra pela que é própria da linguagem empresarial e, assim, não se vai dando conta do mergulho numa perspectiva que mercantiliza e instrumentaliza o conhecimento e, também, a instituição universitária. Embora o dicionário Houaiss dê a ambos os termos o sentido de "ajuda", é em "patrocínio" que encontramos o sentido de apoio concedido "como estratégia de marketing, por uma organização a determinada atividade artística, cultural, científica, comunitária, educacional, esportiva ou promocional". Esse sentido de marketing se coaduna com as atuais condições de produção da ciência, em que as representações marqueteiras do conhecimento criam significados e levam-nos a assumir o lugar do que representam, tornando-se pequenos títeres do conhecimento. A universidade, no entanto, tem outra tradição. 
Em 2005, uma difícil tarefa se apresentou quando fui eleita coordenadora do programa de Pós-Graduação em Geografia Humana, um programa que naquela época tinha cerca de 40 professores e 300 alunos. Vale lembrar que na USP temos dois programas: o de geografia humana e o de geografia física. Trata-se da pós-graduação mais antiga do Brasil, datando sua primeira tese de 1944. Com o formato atual, se desenvolve desde 1969, quando o MEC criou os cursos de pós-graduação no Brasil. Constitui-se em centro de excelência, avaliado com nota 7 , que foi alcançada na minha gestão.

Os anos de 2004 e 2005 foram marcados por um projeto novo e ousado: o campus leste da USP na cidade de São Paulo; mais precisamente, a implantação da USP Leste, uma expansão da universidade numa das regiões mais carentes da cidade. Na ocasião, eu participava do projeto A USP e as Profissões, voltado para divulgar no ensino médio as carreiras e os cursos da USP. Vivenciei a polêmica sobre o uso da preposição: USP da Zona Leste ou USP na Zona Leste? A contenda alcançava até os jornais. Seria uma USP diferente, a da Zona Leste, ou a mesma USP situada nos confins da cidade? Não tive dúvida: na publicação, aboli a preposição - uma de minhas poucas ousadias. Após a publicação de A USP e as Profissões, com uma tiragem de mais de 150 mil exemplares, a discussão nominativa feneceu, e se assumiu o nome sem preposição - USP Leste.

Em 2005, consagra-se um sonho que eu há muito vinha acalentando e supera-se a grande e árdua dificuldade pelo reconhecimento da geografia regional, que evidencia que não se fundamentava num equívoco intelectual, mas em possíveis interesses relativos a questões de concursos na contratação de docentes e na progressão da carreira, bem como na composição das disciplinas curriculares e no uso do espaço físico do edifício do departamento. Tornou-se realidade o laboratório de geografia regional, denominado Laboratório de Estudos Regionais em Geografia (Lergeo), pondo fim ao empenho e à luta por sua institucionalização. Muitas vezes pensei que essa luta se prolongaria até o fim de meus dias na USP. Me achava uma espécie de Dom Quixote lutando contra moinhos de vento ao buscar equilibrar o projeto desse laboratório, um sonho, com a realidade do comezinho, do menor. Como esse personagem, busquei tornar realidade, um sonho. Mas, no rigor do termo, não um sonho de idealista, mas um projeto necessário ao Departamento de Geografia na USP.

A esse triunfo de 2005, soma-se muitas outras realizações, mas também frustrações, como é natural na vida, que é feita de projetos, realizações e embates. Participei de dois concursos para professor titular, tendo sido classificada em terceiro lugar e, posteriormente, em segundo lugar. Todos sabemos o quanto são envolventes esses momentos da vida acadêmica, que se desenvolvem numa atmosfera carregada de ansiedade, com ganhos e perdas. Mas, como disse Fernando Pessoa, "tudo vale a pena, se a alma não é pequena". Em 2006, prestei um novo concurso e me tornei professora titular.

A leitura de Bernard Kayser, um autor que se dedicou, principalmente, ao estudo das dinâmicas contemporâneas dos espaços rurais, com sua concepção de espaços metropolizados e espaços não metropolizados, como destaquei anteriormente, me deu a chave para avançar nas discussões sobre metropolização. Havia sido um clássico da geografia, voltado para as questões do campo que me inspirou e norteou minhas leituras sobre a metropolização do espaço. Abria-se um campo de investigação na confluência das questões urbanas e regionais que me permitiram refletir sobre a urbanização dispersa e o desenvolvimento de regiões urbanas. 
O tema da cidade-região, agora posto não mais como a cidade e sua região colocava de pernas para o ar grande parte do aprendizado assentado na clássica geografia regional. Como um processo natural da evolução do conhecimento buscando compreender as dinâmicas e processos atuais emergiu o tema da megarregião e do da urbanização regional. $\bigcirc$ primeiro apontado por Sassen (2007) e o segundo discutido por Soja (2013).

Significativos também são os grupos de trabalho que se desenvolvem em encontros da Associação Nacional de Pós-Graduação e Pesquisa em Geografia (Anpege) e do Simpósio Nacional de Geografia Urbana (Simpurb), cuja coordenação compartilho com os colegas José Borzacciello da Silva (UFC), Álvaro Ferreira (PUC-Rio), Saint-Clair Cordeiro da Trindade Júnior, Olga Lúcia C. Firkowski (UFPR), Ivan Queiroz (Urca) e Tadeu Arraes (UFG). Esses grupos de trabalho se constituem momentos privilegiados de troca de experiências e de discussões e têm sido tão proveitosos que sempre somos os últimos a deixar a sala. Mas isso não significa o fim do debate, que continua em mesas de bares e restaurantes, bancas de livros expostos, enfim, em qualquer lugar.

Entre tantos encontros, a menção a dois deles - fora do âmbito restrito da Geografia revela a busca pelo diálogo interdisciplinar, muito significativo desde a minha formação. Como exemplo, vale lembrar os encontros da Associação Nacional de Pós-graduação e Pesquisa em Planejamento Urbano e Regional (Anpur), da qual participo desde 1983, quando foi fundada, e do Congresso Internacional do International Congress of Americanists (ICA) desde sua edição 46, em 1983. O primeiro aconteceu em 1875. Nesse congresso, minha participação evoluiu para a de coordenadora de simpósios que se desenvolvem no evento reunindo pesquisadores do mundo todo voltados para a questão urbana e regional da América Latina.

Cada vez mais a participação em encontros, simpósios e congressos deixa a impressão de que a divulgação do conhecimento vai a passos muito mais largos do que os de sua produção. Ritmos diferentes: a pesquisa se dá num compasso de reflexão e de produção que exigem tempo e também solidão e recolhimento para dar espaço às ideias. A divulgação se faz numa velocidade orientada e motivada não só pela exposição do desvendamento dos segredos do real, mas também pela razão midiática e responsiva às lógicas atuais da universidade. Mas esses momentos de diálogo regozijam a alma, pois engendram encontros, expectativas e trocas. Permitem também perceber mais claramente os caminhos e descaminhos da política científica no país.

Um grande aprendizado tem vindo dos projetos de pesquisa desenvolvidos com pesquisadores do Chile e da Argentina. Colaborei para a instituição do primeiro doutorado em geografia do Chile, graças a minha experiência na Coordenadoria de Aperfeiçoamento de Pessoal de Nível Superior (Capes) como representante de área. Com a Argentina, tenho desenvolvido vários projetos de pesquisa, intercâmbio e cooperação com a Universidade de Buenos Aires. E a experiência no CNPq como representante da área de geografia humana e como coordenadora do Comitê de Assessoramento de Ciências Sociais tem me possibilitado conhecer um pouco mais a geografia que se desenvolve no país. Todas essas experiências são novos desafios que me motivam na continuidade do fazer geografia.

Revendo toda essa trajetória, vejo que as certezas dos primeiros tempos tornaram-se incertas. É como se o monocromatismo da juventude se diluísse, trazendo à consciência o fato de haver, entre o branco e o preto, vários tons de cinza. Muitas vezes, o mais sábio e 
prudente é não pensar de forma excludente ou polarizada. Por que reduzir as questões da universidade, quando é fundamental reconhecer que elas são imbricadas numa complexidade infinita? Por que reduzi-las a uma contraposição simples em termos de dualidades? Por exemplo, por que elaborar opções em termos de uma universidade elitista e de privatização do público em contraposição à massificação do ensino superior e a sua popularização? Questões propostas nesses termos nos fazem caminhar numa espécie de esteira rolante de aparelho de exercício físico, cujos passos não transpõem obstáculos, salvo o da pista rolando sobre si mesma.

Essa trajetória aqui descrita procurou contribuir para que a universidade cumprisse suas finalidades. Reitero: suas finalidades, seus fins e não sua missão. Hoje em dia em todos os foros surge uma fala que associa a universidade à missão x, y ou z. Até há pouco, a universidade tinha finalidades, como consta no seu Estatuto. No Artigo $2^{\circ}$ do Estatuto da USP (2002, p. 7), lê-se: "São fins da USP: promover e desenvolver todas as formas de conhecimento [...]". Nesses novos tempos, acariciados por uma "mão invisível", a USP passa a ter missão, expressão que se poderia justificar como uma influência da língua inglesa ou como espelhamento nas universidades estadunidenses. Isso é um fato, mas a explicação não passa de meia verdade, pois seu significado é mais profundo. Entre os vários sentidos da ideia de fim, aparecem os de objetivo e de propósito, ao passo que missão tem duas conotações particulares e específicas. Uma é de natureza religiosa e outra, a de que alguém deve ter a incumbência de executar um pedido ou uma ordem, compromete a ideia de que cabe à universidade estabelecer seus próprios fins. Ou seja, é no seu próprio interior que esse fins devem ser determinados.

No primeiro caso, a palavra missão traz para o interior de uma universidade laica e secular o sentido clerical, que é próprio das universidades confessionais. No segundo caso, a ideia de executar um pedido emanado exclusivamente de outro ente externaliza o projeto da universidade. Cabe-the executar um projeto que se situa fora dela, que é concebido por outrem, que the confere uma missão. Exterioriza-se, assim, o projeto de universidade. E onde ele se situa? No mercado? Os folders de divulgação de nossas atividades devem se espelhar nos folhetos das empresas e nos sites em que a palavra missão é largamente empregada? Mesmo que admitamos inconsciência na substituição das palavras finalidade e objetivo pela palavra missão, seu emprego indiscriminado revela, infelizmente, anestesia de nossa consciência crítica. Como oráculo tutelar, o mercado captura e instrumentaliza a universidade, não se importando em nos fazer sentir como se estivéssemos no Olimpo.

Esses deslizes acabam nos enredando e tornando mais difícil o rompimento com os grilhões mercantis. $\bigcirc$ pragmatismo utilitarista torna-se dominante, distanciando o desenvolvimento de sua tradição humanista. É necessário externarmos toda indignação, para não mantermos represada a indiferença. É preciso tornar o impossível, possível.

\section{Considerações finais}

Em 2015, ocorreu minha aposentadoria compulsória. Completei 50 anos em sala de aula, pois foi em 1965, naquela escolinha de Mauá, na periferia de São Paulo, que proferi minha primeira aula. Esse meio século fez da educação meu compromisso existencial. Na tentativa 
de uma síntese, considero que minhas maiores contribuições podem ser facilmente identificadas em seis frentes de igual envergadura. A primeira, relativa à formação de professores para universidades públicas, onde hoje muitos dos meus ex-alunos atuam como liderança acadêmica e são nomes reconhecidos no cenário da geografia brasileira.

A segunda é a contribuição para o conhecimento da dinâmica urbana e industrial do estado de São Paulo. Longe de qualquer provincianismo que o tema possa aparentemente sugerir, busca compreender os processos mais à frente, ou seja, os mais avançados entre os que se desenvolvem na relação entre o estágio atual do capitalismo e a produção do espaço urbano e regional. Por meio de minhas pesquisas, identifiquei problemáticas da metropolização paulista e questionei interpretações falaciosas da dinâmica regional do estado, entre elas, a de descentralização industrial, que parecia hegemônica. Esse foi o tributo de minha dedicação à pesquisa, rigorosamente acadêmica, cujas motivações foram sempre norteadas pela produção de um conhecimento sensível ao desvendamento de processos que precisavam ser compreendidos e que emanavam de inquietações intelectuais próprias da geografia.

A terceira contribuição a destacar concerne à persistência no desenvolvimento da perspectiva regional em geografia, renovada teórica e metodologicamente e na reflexão crítica sobre a noção de região. Essa é uma noção central da geografia, constituinte e imanente à história do pensamento geográfico.

A quarta contribuição é meu envolvimento com a gestão universitária, que, por dever de ofício, consagrou o dito popular "é dando que se recebe", pois o trabalho imensurável que essa atividade exigiu e que se somou ao anterior ampliou minha compreensão da universidade. Esse envolvimento no centro da política universitária, com discussões sobre diretrizes, planos e ações, se me subtraiu o tempo de me render ao sono, me fez ver o quanto nosso modo de ser na faculdade é indispensável ao desenvolvimento de uma universidade que deve recuperar seus princípios humboltianos, presentes no momento de sua fundação. Foi esse modo de ser e de pensar que emana do espírito da faculdade e que muitas vezes parece estar esvanecendo que garantiu muitos dos acertos em minhas ações e o reconhecimento dos colegas. $\bigcirc$ exercício de compreender divergências, a necessidade de assumir liderança sem arrogância, a atuação na construção de consenso e o exercício da tolerância reafirmaram o sentido da docência, que atravessou cinco décadas e que não prescinde, igualmente, dessas atitudes e posturas.

A quinta contribuição situa-se no âmbito da extensão universitária, sobretudo dizendo respeito à responsabilidade social pela qualificação dos professores de ensino médio, sempre a serviço do fortalecimento do sistema público de educação. Também se refere à cooperação com outros programas de pós-graduação.

A sexta contribuição é a formação dos alunos de graduação, que sempre responderam afirmativamente aos questionamentos que propus. Inspirada nos ensinamentos de meus mestres, que me mostraram o significado da docência formadora exigente de leituras e trabalhos sistematizados, bem como de rigor metodológico, sou tida por muitos como uma professora experiente e rigorosa. Considerei sempre a aula e os momentos de interação entre o ensino e a aprendizagem como oportunidades de desenvolvimento da consciência emancipatória, não só do conhecimento geográfico e prática de pesquisa referidos à capacidade analítica e crítica da realidade e da síntese das interpretações, mas momentos de desvendamento de construção de 
um conhecimento desmistificador, de desenvolvimento pleno do indivíduo e da cidadania. Por isso, momentos de interação e cooperação na informação, e não de disputa entre opiniões. Acima de tudo, momentos de desenvolvimento da responsabilidade social, por terem o privilégio, neste país socialmente injusto, de usufruir o ambiente de uma universidade pública.

Essas contribuições se pautaram no exercício da autonomia, da cooperação, do respeito às normas institucionais, bem como na assunção de responsabilidade para com os destinos da universidade. Desenvolveram-se no interior das contradições próprias da lógica universitária e nas tensões que lhe são imanentes.

\section{Referências}

MARTINS, J. S. (Org.). Henri Lefebvre e o retorno à dialética. São Paulo: Hucitec, 1996.

PROPOSTA EDITORIAL. Espaço \& Debates, n.-1, 1981.

SANTOS, M. O trabalho do geógrafo no Terceiro Mundo. Trad. Sandra Lencioni. São Paulo: Hucitec, 1977.

SASSEN, S. El reposicionamiento de las ciudades y regiones urbanas en una economía global: ampliando las opciones de políticas y gobernanza. Eure - Revista Latinoamericana de Estudios Urbano Regionales, Santiago de Chile: Instituto de Estudios Urbanos y Territoriales, v. 33, n. 100, p. 9-34, dic. 2007.

SOJA, E. W. Para além de postmetropolis. Revista UFMG, Belo Horizonte, v. 20, n. 1, p. 136-167, 2013.

USP. UNIVERSIDADE DE SÃO PAULO. Estatuto da USP. Secretaria Geral. 2. ed. São Paulo, 2002. 